\title{
China as dystopia: Cultural imaginings through translation
}

Published in: Translation Studies (Taylor and Francis) doi: 10.1080/14781700.2015.1009937

Tong King Lee*

School of Chinese, The University of Hong Kong

*Email: leetk@hku.hk

This article explores how China is represented in English translations of contemporary Chinese literature. It seeks to uncover the discourses at work in framing this literature for reception by an Anglophone readership, and to suggest how these discourses dovetail with meta-narratives on China circulating in the West. In addition to asking "what gets translated", the article is interested in how Chinese authors and their works are positioned, marketed, and commodified in the West through the discursive material that surrounds a translated book. Drawing on English translations of works by Yan Lianke, Ma Jian, Chan Koonchung, Yu Hua, Su Tong, and Mo Yan, the article argues that literary translation is part of a wider programme of Anglophone textual practices that renders China an overdetermined sign pointing to a repressive, dystopic Other. The knowledge structures governing these textual practices circumscribe the ways in which China is imagined and articulated, thereby producing a discursive China.

Keywords: translated Chinese literature; censorship; paratext; cultural politics; Yan Lianke

\section{Translated Literature, Global Circulations}


In 2007, Yan Lianke (b.1958), a novelist who had garnered much critical attention in his native China but was relatively unknown in the Anglophone world, made his English debut with the novel Serve the People!, a translation by Julia Lovell of his Wei renmin fuwu (2005). The front cover of the book, published by London’s Constable, ${ }^{1}$ pictures two Chinese cadets in a kissing posture, against a white background with radiating red stripes. The back cover is red - the colour scheme is, of course, evocative of the Chinese national flag and of Communism. This association with the Chinese political establishment is highlighted in the following lines, centred at the top of the back cover in white lettering, upper case, and bold type:

\section{BANNED IN CHINA ${ }^{2}$}

\section{THE SEXY, SATIRICAL SENSATION}

The "sexy" and "sensational" nature of the novel is further explicated in a blurb which once more highlights its banned status:

Yan Lianke tramples on the sancrosanct taboos of the army, the revolution, sexuality and political etiquette in this funny, subversive critique of official corruption, leadership hypocrisy and the insanity of the Cultural Revolution. His first work to be translated into English, Serve the People! brings us one of the most important voices still writing from inside China today.

This sexually charged political satire by one of China's most distinguished authors was instantly banned in its native China, with propaganda ministers reportedly apoplectic 
about its depiction of the People’s Liberation Army during the Cultural Revolution. (Yan 2007, back cover)

It is apparent that the censorship of Yan's book is the central theme in the marketing of the translation. One could speculate that this censorship is the very motivation for translating the work. This claim finds support in the anonymous introduction to the book (probably written by the editor or translator), which recounts the Chinese government's suppression of this and other novels by Yan, foregrounding his cult status.

All the state publishing houses refused to publish Serve the People!, but finally excerpts of the novel appeared in January 2005 in one of China’s top literary magazines [...] The censors ordered the magazine to recall the entire issue. 'This novella slanders Mao Zedong, the army, and is overflowing with sex,' said the edict by the propaganda department quoted in the South China Morning Post. 'Do not distribute, pass around, comment on, excerpt from or report on it.' (Yan 2007, n.p.)

The use of "edict” here is significant: the anachronistic word recalls images of ancient Chinese emperors and courts, reinforcing the text's critique of totalitarian censorship. This ties in with a subsequent remark by Yan quoted in the same introduction: "Writers should pay attention to the emotional lives of the masses, births, deaths, and intolerable humiliation, the desperate situations of their existences. They are the majority, but our literature happens to have abandoned them” (Yan 2007, n.p.; my emphasis). The text's rhetoric is such that the dichotomous opposition between authoritarian government and the suppressed masses stands out in sharp relief. 
What is interesting about the textual material surrounding Yan’s novel is the image of China, ${ }^{3}$ or of Chineseness - an imagined essence of China - that seems to appeal to the sensibilities of English-language publishers and, by extension, their target readership. This image is one of a monolithic political state that is inexorably tyrannical ("official corruption, leadership hypocrisy and the insanity of the Cultural Revolution”) and, therefore, different from the democratic West. This China censors honest and talented writers like Yan who venture into the taboo territory of politics. Serve the People! narrates the forbidden sexual liaison between the young wife of a Communist military commander and a young cadet during the Cultural Revolution. The affair is itself scandalous, but the most sacrilegious act committed by the couple is that of defacing the statue of the deified Mao Zedong, and of destroying the ubiquitous "Little Red Book”, the Chinese Bible that records Mao’s teachings. The novel’s banning in China therefore comes as no surprise, but this unfortunate event of literary censorship also turns into a resource that propels it, together with its author, into global circulation.

In the global circulation of literature, translation is a critical link. It enables a literature to propagate itself, or be propagated, beyond the original language of its creation. The literary exchanges that come about through translation are the basis of what we call world literature (Damrosch 2003). Through translation, literatures with higher symbolic capital export themselves and extend the frontiers of their influence into peripheral zones in the world literary marketplace. On the other hand, literatures with lower symbolic capital would have themselves “consecrated” through being translated into more globally prestigious languages, thereby increasing their exposure in the international "republic of letters" (Casanova 2004).

In reality, the directionality of translation indexes unequal power relations between languages and literatures. Translation tends to take place from languages and literatures with 
higher symbolic capital toward those holding less capital. Statistics provided by Lawrence Venuti $(2008,11)$ illustrate this asymmetry: in Britain and America, the percentage of translated works is well below 3\%; the corresponding figures for French, Italian, and German publishers are much higher. This indicates that as an international lingua franca, English is much more frequently translated out of than it is translated into. This observation is in accord with polysystems theory, which tells us that when a culture perceives itself to be strong or self-sufficient, the position of translated literature in that culture is likely to be marginal (Even-Zohar 1990/2012, 164).

This makes the case of Yan Lianke in English translation an intriguing one. In contemporary global literature, Chinese fiction is a relatively minor polysystem, and it is only relatively recently that contemporary authors have come to be systematically introduced into the Englishspeaking world. What is it, then, that makes a novel such as Serve the People! attractive to Anglo-American publishers? Is it its "subversive critique of the hypocrisy and madness of the Cultural Revolution”, coupled with the fact that Yan was subject to state punishment for writing politically incorrect novels? ${ }^{4}$ Or is it the "intolerable humiliation”, allegedly endured by the masses in China, and "the desperate situations of their existences" (Yan 2007, n.p.) depicted by Yan and his contemporaries? What discourses are at work in framing these translated works for reception by an English-speaking readership, such that political subversiveness turns into a tactical motif in marketing translated literature? And how do such discourses dovetail with metanarratives on China in the West?

\section{Imaging and Imagining in Translation}

These questions pertain to the construction of images of alterity through translation. This imaging function of translation, closely related to the imagining of the Other, is well-attested in cultural 
studies of translation, where translation is seen as "a primary instrument through which one culture both learns about another, but at the same time constructs its image of that other culture” (Bassnett 2014, 32). Translation is never, as it were, purely a means of cross-cultural communication; it is as much about cross-cultural construction. What is the relationship between images of a culture and the represented culture in reality? To André Lefevere, images exist "side by side with the realities they [compete] with, but the images always [tend] to reach more people than the corresponding realities” do $(1992,5)$. Translations, as an influential form of rewriting, "are produced in the service, or under the constraints, of certain ideological and/or poetological currents" (ibid.). This happens especially when the source text is written in a minority language (Spivak 1993/2012; Niranjana 1992; Henitiuk 2014). As Mona Baker (2006, 105-140) illustrates, through various kinds of framing devices, translators can subtly reposition the source text in favour of certain ideological discourses - a phenomenon that has severe implications in politically-charged situations.

But ideological and poetological currents are always in operation in shaping the reception of translated literatures. In her study of the reception of Australian literature in Italian translation, Rita Wilson demonstrates that the idea of "Australianness" is underscored by distinctive traits that tend toward the exotic, where Australia is popularly known as a "distant frontier" marked by vast wilderness and rusticity. This general perception guides the choice of specific titles and authors for translation, which 'reflect[s] the target readers' interest in the foreign culture underlying the text” (Wilson 2013, 181). A cyclical trend ensues, where the translations of select Australian fiction often confirm stereotypical imaginings of the continent as "outback", constructing and propagating it as "a utopian ideal associated with immense and unspoilt natural landscapes bathed in brilliant light” (ibid.). 
The popular imagination of a foreign culture and the literary image of that culture feed into each other continuously. The former is primarily engendered by the media, the latter through translation. The economic component in no way mitigates the strength of the underlying ideology, but rather exacerbates it: publishing houses, driven by profits, orientate their lists of translated titles and marketing strategies to accommodate the reading habitus of their readers. By reading habitus, I mean particular dispositions toward certain foreign cultures on the part of readers; these dispositions are, at least in part, brought into being through education, socialization, and prolonged exposure to media narratives about the foreign culture in question. ${ }^{5}$ The literary images constructed through translation reinforce a priori cultural preconceptions, which then fuel publishers to bring out more translated products along similar lines. The loop closes, enabling discourses and cultural artefacts to thrive in tandem in a self-justificatory bind.

The reason why literature and literary translation can participate/conspire in the representation of foreign cultures lies in their metonymic nature. A literary work, as Maria Tymoczko maintains, "customarily evokes its culture through consequential and telling signals or details, typically parts or aspects of the culture that are saturated with semiotic significance and emblematic of the culture as a whole” $(1999,45)$. It follows that literary works, when published systematically in line with some encoding principle or agenda, coagulate into a kind of collective discourse. This literary corpus, which has the potential to expand and evolve over time, then functions to represent and recall a culture writ large - a culture that is, at least in part, discursively imagined into being and that exceeds the sum of the published content. A book may also evoke other books purportedly of the same thematic category. Just as a written mythic tale may evoke "a vast body of tale types and archetypal patterns which the myth reworks and reanimates" (ibid., 43), so books labelled thematically as “China” or "Asian Studies” can 
expound on one another. This reinforces the archetypal category circumscribing them, which in turn generates more members for the said category.

The act of translating literature, too, is metonymic; it is a form of representation in which parts or aspects of the source text come to stand for the whole (Tymoczko 1999, 55). The propensity of translation to partially represent is critical, for it is this property that enables translation to be exploited as a means to image a culture, as if it exemplifies that culture in its entirety. Just as a single translation is only a partial representation of a source text but stands in for the whole, so an institutionalized translation programme, while representing only a part of the reality in a foreign culture, can purport to represent or survey the whole of that culture. Such representations are always governed by higher-level ideological discourses, which ensure the logicality and coherence of the micro-discourses at the level of the text. Eventually they generate a sort of quotidian sensibility that flows back into the system of discourses and publishing agendas.

Thus, it is thanks to the metonymic nature of translation that it acquires the capacity to represent, even based on a relatively small and partial corpus of textual artefacts. Such a capacity affords translation "enormous power in the construction of identities for foreign cultures", and to potentially become complicit in "ethnic discrimination, geopolitical confrontations, colonialism, terrorism, war" (Venuti 2008, 14). If, in the case of Australian literature, "some dissemination of ideas and information, some nuanced views on Australia and perhaps increased empathy and understanding” (Wilson 2013, 189) have been effected through its Italian translations, the situation does not sound nearly as positive for China. Like Australia, China is imaged and imagined as a community radically different from the "West" - itself an imagined construct, of course. But while Australia is pictured as some kind of utopian land in the Western fantasy, I 
would argue that China is unambiguously seen as a dystopia. Instead of "increased empathy and understanding”, translation performs a deepening of established Eurocentric views of what modern China essentially is. The essentialist characterization of China in the West arises from the systematicity with which China is discursively constituted through myriad forms of media (Liss 2003; Frayling 2014; Turner 2014), of which literary translations are a part. The following paragraphs will illustrate this by looking at several contemporary Chinese titles in English translation, with special attention to their paratexts.

\section{Paratexts in Translation: Discursive Formations of the Cultural Other}

Paratexts are an exceptional window through which insights may be gained on how literary works are received. A piece of literature, including its translated version, is "rarely presented in an unadorned state, unreinforced and unaccompanied by a certain number of verbal or other productions" (Genette 1997, 1) that expound on it in various ways. It is these "verbal or other productions” that we turn to in this section with reference to contemporary Chinese literature in English translation. Besides investigating “what gets translated”, I am further interested in how Chinese authors and their translated works are positioned, marketed, and commodified through the discursive material that surrounds a translated book.

The commodification of literary products is guided by the economy, as well as the economics, of the publishing industry. Marketing strategies point to prevailing reading tastes. What we call "taste" is never purely a matter of aesthetics or subjective preference; instead, it is loaded with cultural values, especially when foreign literatures are involved, and is more likely a communal disposition shaped by a shared (though latent) discourse than an idiosyncratic choice. Every work of literature on the market bears a mark of its own positioning with respect to other 
contemporaneous cultural products. This positioning is intimately tied to considerations of marketability and profitability. And it is by virtue of this economic link that a book's positioning reflects the horizon of expectation of the reading public and critical community, which constitutes the dominant poetics and ideology governing literary reception. In short, for economic reasons publishers generally promote a literature in a way that confirms or strengthens current beliefs and perceptions about this literature and its attendant culture or subculture.

One way of gaining a handle on these beliefs and perceptions, therefore, is to look at publishers' paratexts. The paratext serves as a powerful interface that mediates the relationship between a published text and its readership; it is "a zone not only of transition but also of transaction: a privileged place of a pragmatics and a strategy, of an influence on the public, an influence that $[\ldots]$ is at the service of a better reception for the text and a more pertinent reading of it” (Genette 1997, 2; emphasis in original). In other words, paratexts pivot readers' orientation toward the text before it is even read, which helps to generate the desired interpretation. Genette (1997) makes a distinction between two types of paratexts: whereas "peritexts" (cover page, book jacket, table of contents, preface, blurb, etc.) appear within the material book itself, “epitexts” are external, such as reviews in a literary journal. In the case of translated literature epitexts may turn into peritexts: book reviews, for instance, are very often excerpted and printed on book jackets to highlight the critical acclaim received by a novel or collection of essays.

The following section will show how China, as an imagined polity, is in part discursively constructed through translation. Although my concern is mainly with literature, it is important to note that literary and non-literary texts, both translated and non-translated, belong to the same constellation of textual objects that circulates images of China in the global marketplace. Occasional references will thus be made to writing in non-literary genres to illustrate how textual 
practices collaborate within a more general meta-narrative in shaping Anglo-American imaginations of China. I focus on a number of contemporary Chinese titles in English translation, including works by Ma Jian, Chan Koonchung, Yu Hua, Su Tong, and Mo Yan. There are two reasons for this scope of analysis. On quantitative grounds, US and UK publishers have been extremely active over the last 10 years in making available translations of contemporary Chinese writing. This provides an ample supply of data on which to base my claims. The other reason is that this research is envisioned as part of a larger project on discursive practices and the power dialectic between China and the West since 1989 (the watershed year of the Tiananmen Incident). This project positions contemporary writing as one of the channels through which China's soft power is projected and potentially mitigated in the West. An examination of contemporary Chinese literature in English translation thus has the potential to raise questions pertinent to today’s China-West cultural politics.

\section{The Attractions of Political Taboo}

The example of Yan Lianke’s Serve the People!, introduced above, illustrates a central theme that underlies contemporary Chinese literature in English translation: political taboo (Lovell 2006, 3234; Edwards 1995/2013, 272-275). This suggests that political opposition to a text in China may increase its appeal in the Anglophone market. This is testified to by Yan’s popularity among English translators and publishers. From relative obscurity, Yan has risen in just a few years to become the first Chinese winner of the prestigious Kafka Prize in 2014. It is interesting to note that out of Yan's many books, those translated into English are exactly the "problematic" ones from China's perspective. After his debut with Serve the People!, two other novels were translated and published. Dream of Ding Village (Yan 2011), translated by Cindy Carter, is the 
translation of Yan's 2006 novel Ding zhuang meng, which was banned from release by Chinese censors. A blurb on the back cover of the Consair edition highlights Yan's status as “China's most controversial writer", and describes how the novel "was stopped in its tracks, with a 'no distribution, no sales and no promotion’ order”. It remarks that “[t]he risks to [Chinese] publishers are now so high that Lianke doesn’t know whether he'll be able to find a Chinese home for his next book” (Yan 2011). The novel is said to deliver Yan's “characteristic black humour and daring satire", which makes for "a powerful allegory of the moral vacuum at the heart of communist China" (my emphasis). To further emphasize the point, the blurb invokes Serve the People!, referring to it as "an underground internet sensation”. By underscoring the taboo nature of Dream of Ding Village and its predecessor, literary agents (publishers, editors, translators) create the enticing narrative of a forbidden novel being heavily repressed because it reveals too many of China’s "dark secrets”, and eventually finding its liberatory channels in the West.

Reviews of the novel are reappropriated as peritexts on the back cover of the book. Clipped and quoted from their respective contexts, these critical excerpts show remarkable centripetality in their interpretation of the novel. Thus, reportedly "[w]ritten after three years of clandestine research” (Library Journal), Dream of Ding Village is seen as “a devastating critique of China's runaway development” (Guardian), “[a] brutal morality tale of a country undergoing transition” (Library Journal), “[a] sorrowful but captivating novel about the price of progress in modern China (Kirkus Review). It is “a true revelation” about “an alarming situation” (Rolling Stone), where "Communist ideals battle against capitalistic impulses and human nature" (Booklist) (observe how, through such rhetoric, capitalism is constructed as being in alignment with human nature, with the implication that communism is unnatural). With "unflinching irreverence”, Yan 
"shines another grim spotlight on China’s abuses" (Library Journal) with his "lyricism of despair" (Le Monde), making this “Schadenfreude tragedy” (Library Journal) “a must-read for anyone interested in present-day China” (Booklist). ${ }^{6}$

It is noteworthy that Yan's novel should be recommended as a "must-read" for those who desire to learn about contemporary China: this construes the fictional work as a source of objective knowledge, a documentary rather than literary text. To the Anglo-American audience, Chinese literature is not so much entertaining as it is informative. Thus, in the English translation of Yu Hua's China in Ten Words (Yu 2012), a review by Publishers Weekly tells us that the book “[o]ffers rare insight into the cause and effect of China’s 'economic miracle”, while another by the US-based writer Ha Jin says that the essays "form a small kaleidoscopic view of contemporary China”. This paratextual emphasis on the informative is less neutral than it might seem. The critical discourses surrounding translated Chinese texts often take the opportunity to launch a political critique by referring to landmark events in Chinese history that demonstrate a breach of human rights. The following review by Orville Schell, Arthur Ross Director of the Center on U.S.-China Relations at Asia Society, is telling:

In this era of the China Boom, when Communist Party officials are so inclined to erase the travails of their country's past from public consciousness, Yu Hua's insistence on remembering comes as an almost shocking intrusion into a willful state of amnesia. His earthy, even ribald, meditations on growing up in small-town China during Mao's Cultural Revolution remind us of just how twisted China's progress into the present has been and how precariously balanced its success story actually still is. (Yu Hua 2012, back cover) 
This is Schell's elaborative interpretation of China in Ten Words. By steering the work strategically toward sensitive key words and phrases such as “Communist Party”, “Mao’s Cultural Revolution”, “twisted progress”, the reviewer and publisher (Schell’s review is printed on the back cover of the book, which makes the publisher complicit) shape Yu Hua's essays into reliable source material on China’s “dark” history.

These examples illustrate a continuity between the function of a literary text and that of a historical text that purports to document factual events such as Yang Jisheng's Mubei (Tombstone) (Yang 2012, 2013). Yang's work seeks to document the Mao Zedong-era agrarian movement called the Great Leap Forward (Da yuejin), better known in the West as the Great Famine. Yang's relentless depiction of the cruelty and suffering witnessed during this period of recent Chinese history places his work within the same discursive framework as, say, Yan’s novels, even though on the surface it belongs to a wholly different genre. The publishers not only exploit the fact that it is forbidden in China (the Chinese original was published in Hong Kong), but also foreground the fact that it tells an "untold story" that “draws on the author's privileged access to official and unofficial sources to uncover the full human cost of the tragedy” (Yang 2013, back cover). Here a palpable aura of clandestineness is built around the work through the paratext, which positions the work as a piece of classified history.

Another example of translated Chinese literature which has come to assume the informativeideological role of sociopolitical exposé is Yan’s Lenin’s Kisses, translated by Carlos Rojas and published by Vintage in 2013. A review excerpt from the Spectator on the back cover reads: “Yan Lianke movingly chronicles the price that Communist China's rush to get rich has exacted from its vulnerable rural majority” (Yan 2013; my emphasis). Here the verb “chronicle” is really more literal than rhetorical; it points to the didactic in the novelistic, and the message is that 
contemporary China is rife with bureaucratic corruption and anti-human rights events. And that is, of course, what Lenin’s Kisses is “essentially about”. This purported aboutness is partly attributable to the storyline (a Communist Party official exploits a quaint village inhabited by physically handicapped people by turning it into a commercialized tourist spot), but also partly a paratextual effect. The evidence for this lies in the Translator's Note (Rojas 2013, v-ix), which not only provides a synopsis of the novel but also fixes the reader's initial impression of the book by foregrounding its forbidden nature. Shouhuo, the Chinese original of Lenin's Kisses, was not technically banned in China when it was published in 2004 (in fact, it won a prestigious Chinese literary award). But it nonetheless touched sensitive nerves: the translator tells his readers that Yan was sacked by the People’s Liberation Army, his then employer, following the publication of the novel. Importantly, Rojas builds an intertextual link with Yan’s other (banned) novels, namely Serve the People! and Dream of Ding Village, thereby subsuming Lenin's Kisses, a perfectly "legitimate" novel in and of itself, into a trilogy of censored fiction. To elaborate his point, the translator further quotes Yan’s blog post on the “castration of literature” (Rojas 2013, xiii), an intense metaphor alluding to censorship. Rojas then focuses on a structural feature of the novel - that of using only odd numbers to enumerate chapters and notes, eliding all even numbers - and offers a politicized reading: the numbering scheme is "a tacit reminder of everything the novel necessarily leaves unsaid as a result of Yan's delicate courtship with China's censorship system” (ibid., viii-ix). This is in spite of Yan's own explanation of his numbering system (i.e. that odd numbers are unlucky numbers to the Chinese, see Yan 2004), which is much less dramatic. The translator calls the missing chapter numbers "proverbial cracks produced by contemporary China's tectonic shift from high communism to hypercapitalism - citizens inadvertently sacrificed by a logic of economic progress that purports to be advancing the 
interests of the nation as a whole” (Rojas 2013, ix). The theme of Yan’s novel - as interpreted by the translator - is elegantly encapsulated within a larger narrative circulating in Western media discourses about the paradoxical hybridity of a communist-capitalist China.

What accrues from these paratextual materials is a self-evident image of Yan Lianke as a dissident writer repressed by the Chinese authorities. It is “self-evident” because it receives discursive fertilization from popular Western rhetoric denouncing China as an abuser of human rights. But while it is true that two of the three novels mentioned above have been formally banned, from the Chinese perspective one would be hard-pressed to label Yan as a "dissident writer”, given that Yan has, at the time of writing, more than forty novels and short story collections under his belt - all by established mainland Chinese publishers. Judging from the sheer quantity of his works on the market and the status of his publishers, Yan is clearly mainstream, notwithstanding the fact that a small number of his novels have been prohibited. This is a far cry from the iconoclast status that seems to shape his English-translated persona. It shows how Yan's literary image in the West is manipulated through the strategic selection of texts to be translated. By excluding other less ideologically overt, and therefore less “sensational”, novels by Yan, this discursive loop generates a powerful narrative of literary victimization, one that locates allegedly politically-minded writers in diametric opposition to the Chinese institutional machinery.

Yan is not alone when it comes to literary censorship; he is joined by Ma Jian, whose 2008 novel Beijing Coma was banned in China, and subsequently taken up by Vintage in 2009. The translation seems as motivated by the politically sensitive nature of the novel as was the ban. The story, as summarized on the back cover of the book, follows a Chinese man from "his harsh childhood in the last years of the Cultural Revolution” to the Tiananmen Incident, during which 
he is shot in the head and falls into a coma. The two darkest episodes in contemporary Chinese history (the first a decade-long proletarian exercise, and the second a military crackdown on student protesters seeking democracy) turn into critical marketing points. This becomes clear in the blurb, which again points to the capacity of the novel to inform, telling us that this is "an outstanding work of fiction and an extraordinary insight into modern China” (Ma 2009; my emphasis). The implication is that modern China is an entity that can be abstracted and captured in works of fiction. Excerpts from two reviews corroborate this claim: the Times positions the book as "a landmark account through fiction of a country whose rise has amazed the world, but which remains cloaked in shadows", and the Guardian sees the novel as "a mighty gesture of remembrance against the encroaching forces of silence”.

The same discursive mechanism is at play in Hong Kong writer Chan Koonchung's satirical novel Shengshi, first published by Oxford University Press (Hong Kong), and translated by Michael Duke as The Fat Years (Chan 2012). The publication of the English translation was sponsored by English PEN, an organization that campaigns "to defend writers and readers in the UK and around the world whose human right to freedom of expression is at risk” (English PEN). This sponsorship, in effect a form of patronage, itself tells us a great deal about the ideological position of the book. The Fat Years is an Orwellian satire of contemporary China that tells the story of a totalitarian regime that tames its people by obliterating key political events from their memory and, therefore, from historical records. The allusion to China cannot be missed, and readers are continually reminded of this via review excerpts on the book's front cover, inner page, and back cover: the novel "reveals the distorted reality of China, where despite the supersonic development of its economy, political life is steadfastly unchanging” (review by Ma Jian); it is “a not-so-veiled satire of the Chinese government's tendency to make dates such as the Tiananmen 
massacre virtually disappear” (Financial Times). It is notable that this latter review uses "massacre" rather than "incident" to highlight the violence of the Tiananmen event ${ }^{7}$. Readers are guided to read the novel allegorically, so that they can appreciate its relevance to the contemporary Chinese situation: "The Fat Years remains valid because it is not simply a 'what might happen' exercise in futurism. Its central conceit - that collective amnesia overtakes the entire country - is an all-encompassing metaphor for today's looming superpower" (Observer); ${ }^{8}$ "[t]his creepy novel frightened me several times...because, apart from the missing month, it is mostly true today” (Spectator).

Three other paratextual devices in The Fat Years function to prime readers' interpretation. The first is a preface by Julia Lovell, who points to the novel's “unusual honesty about certain aspects of contemporary Chinese reality” (Lovell 2012, 15). The second is the Translator's Note (Duke 2012a, 300-307), in which the translator spells out in explicit terms the politicalideological implications of the novel as a whole. The third is the Translator's Endnotes (Duke 2012b, 308-318), which explicate the sociopolitical circumstances or events alluded to by certain phrases in the novel. Most of these phrases refer to political events obliquely in the main text, ${ }^{9}$ and it is highly likely that even a native Chinese reader may miss some of their implied meanings. The reader of the English version is faced with a "thick translation" (Appiah 1993/2012), where a full load of contextual - especially political - knowledge deemed necessary for the "proper" understanding of the novel's message is laid out in meticulous fashion. Indeed, the information provided is excessive, extrapolative, and extensional; it seeks to elucidate every possible reference to Chinese politics, so as to transform the allegorical novel into an expository text.

The sensational value that derives from publishing prohibited works in translation explains why controversial Chinese writers are able to find themselves a place in the Anglo-American 
publishing industry. A piece of censored literature is sensational because, notwithstanding the content, its very existence embodies a repression of the freedom of expression. ${ }^{10}$ Western readers are primed to see the repression of free expression as symptomatic of an undemocratic regime that prioritizes political order over individual rights (and this is not a value-free claim in itself). Censored works therefore tell a story, not in the sense of their fictional plotlines, but of a discourse that creates an invisible link between translated literature as a generic whole and the values they are made to represent. In other words, publishers generate and fulfill their readers' curiosity about a despotic China through the "selective appropriation of textual material" (Baker 2006, 115-118). This is epitomized in the translation and dissemination of works by the political dissident Liu Xiaobo, the 2010 laureate of the Nobel Peace Prize. Two books by Liu have been published so far for the Anglophone market: a bilingual volume of poems entitled June Fourth Elegies, a clear reference to the Tiananmen Incident (also known as the June Fourth Incident in Chinese), ${ }^{11}$ and No Enemies, No Hatred, a collection of Liu's essays and poems translated into English. Liu, of course, has an unequivocal, anti-Communist stance, and most of his writings are indeed critical of the PRC establishment. It is therefore unremarkable that the paratexts that surround Liu's texts (Liu 2012a, 2012b) elaborate on his political circumstances, especially his incarceration by the authorities for his alleged role in popularizing an anti-establishment manifesto. My point, however, is that Liu's case represents only an extreme version of a metanarrative that governs the making of a consistent image of China in literary translation. Once this meta-narrative is in motion, it becomes an automatic discursive mechanism that converts every Chinese author and his texts encountered by the Western audience into a potential ideological site. Above, we saw how Yan Lianke is consciously shaped into a repressed novelist through selective translation and paratextual construction, even though he is not necessarily seen as such by 
Chinese readers. This indicates the domesticating, normalizing effect that higher-level discourses have on the manipulation of reader perception towards contemporary Chinese literature.

\section{Exoticising the Chinese Canon}

Even for authors who are much less controversial than Yan Lianke, the paratextual strategies described above can be seen at work. The most high-profile authors from China, including, among others, Yu Hua, Su Tong, and the Nobel Laureate Mo Yan, are widely translated in the Anglophone world. What is interesting is the high degree of consistency between the way the works of these authors are paratextually marked/marketed and that adopted for works that carry a political taboo, as discussed earlier. In 2014, a collection of short stories by Yu Hua was published by Pantheon Books. It bears the title Boy in the Twilight, the translated title of one of its pieces. There is also an added subtitle, which reads "Stories of the Hidden China". Two linguistic details deserve mention: first, the definite article is used, leaving no room for speculation as to which "China" is being referred to - it is the, yes, that China already familiar to the Western audience; second, the preposition of indicates a possessive relation, hence these are “China’s stories”, that is, stories that represent China. It is not merely a matter of provenance, which would be far better expressed by the preposition from. The word "hidden" adds an element of mystique. At the outset, the grounds are prepared for an exotic read: the tales are supposed to come from a "hidden", hence clandestine, hence obscured, hence enigmatic China; it is a China ("Them") "hidden” from, therefore profoundly strange to, the Anglophone West ("Us”). This is no doubt a structure emanating from a certain vision of reality (cf. Said 1978/2003, 43), as we have observed a similar Self-Other dichotomy with the taboo works. 
In line with this structure, as activated in the subtitle, we are told that Yu Hua's stories "sketch vignettes of everyday life in contemporary China" that reveal "the fractures and fluidities in human relationships during the reform era in China” (Yu 2014, vii). The choice to foreground the temporal-political dimension - the "reform era in China" - focuses the English reader's attention on an objectified entity encased in some alien, past era. At the same time, there is an emphasis on the mundane and cruder modes of living in China that promises to bring the reader far away from Western civilization and into a distant geographical-cultural space. Thus, the blurb on the book jacket says the collection contains "[t]hirteen audacious stories that resonate with the beauty, grittiness, and exquisite irony of everyday life in China", and that "take us into the small towns and dirt roads that are home to the people who make China run” (ibid., n.p.; my emphasis). The point here is that even with canonized authors, English publishers tend to seek out an exoticized Chineseness that appeals to a Western imaginary. And they are invariably successful, insofar as this exoticized Chineseness is always a discursive and rhetorical effect materialized in the form of paratexts. The ostensibly informative function of translated literature retains its grip. . We see this in Su Tong's Tattoo, introduced as "a new collection of novellas that ranges from mystery in swinging prewar Shanghai to the violent gangs of the Cultural Revolution”; it supposedly demonstrates "mastery of the full sweep of twentieth-century China” (Su 2010, back cover). Shanghai and the Cultural Revolution have effectively become political signifiers that point uniformly to a negative China. ${ }^{12}$ Indeed, the choice of the title is telling in itself. The book contains three novellas: “Tattoo”, "Divorce Handbook”, and “The Gardener’s Art”; one speculates that the first may have been chosen as the book's title for its exotic overtones.

In Mo Yan's The Republic of Wine, the translation of Jiu Guo (1992), a blurb praises the work as "both mesmerizing and exhilarating, proving that no repressive regime can stifle true 
creative imagination” (Mo 2012, back cover). Here the reference to "repressive regime” is superfluous; it does not pertain to the plot of the novel but points extra-textually to the Communist government. Details such as these may seem minute and piecemeal, but their cumulative effect must not be underestimated, as a broader discourse ensures their internal coherence. Thus, in Life and Death are Wearing Me Out, the English translation of Mo Yan’s Sheng si pi lao (2006), Mo Yan is branded "the most revered, feared, and controversial Chinese writer” (Mo 2006). The English reader unfamiliar with the Chinese literary scene may take this at face value, in which case a misperception would arise. It is one thing to acknowledge that some of Mo Yan’s novels are political allegories, and quite another to say that he is "feared” and “controversial”. Yet these are the very motifs that publishers persistently cling on to in making sense of Chinese authors to their readers. In Mo Yan's Red Sorghum, the translator Howard Goldblatt even takes care to specify in a note on the copyright page that "[a]t the request of the author, this translation is based upon the Taipei Hong-fan Book Co. 1988 Chinese edition, which restores many cuts made in the mainland Chinese edition, published in 1987 by the Liberation Army Publishing House in Beijing” (Mo 2003). By highlighting the fact that the translation is based on an unabridged version of the Chinese novel, the translator alerts his readers to the fact that the claws of censorship did come upon Mo Yan, and that he is resisting this by approving an English translation based on an uncensored version.

One also observes that the Chinese authors who are turned into informants on the sociopolitical situation in China are simultaneously recognized as legitimate members of the Western literary establishment. This is indicated by paratextual mention of awards won by these authors. While it is a common marketing strategy for publishers to highlight the accolades won by literary authors in general, the case of Chinese writers is particularly significant: it is primarily the 
international, as opposed to the local, awards afforded them by Western institutions that count and are mentioned. For example, on the book jacket of China in Ten Words, Yu Hua is introduced as the winner of the James Joyce Award, France’s Prix Courrier International, and Italy’s Premio Grinzane Cavour. To the same effect, critics or publishers often compare Chinese authors with Western literary figures, who serve as an implicit benchmark against whom Chinese authors are evaluated. Mo Yan’s work has been lauded as being “akin to that of Gorky and Solzhenitsyn” (review by Washington Post, quoted in The Garlic Ballads and The Republic of Wine). ${ }^{13}$ He is said to deserve "a place in world literature”, where "[h]is voice will find its way into the heart of the reader, just as Kundera and Garcia Márquez have” (review by Amy Tan, quoted in The Garlic Ballads and Red Sorghum). Chinese authors are thus paradoxically seen as "Us” and "Other" at the same time: through being endorsed by Western institutions and with reference to Western canonical writers, they gain the necessary symbolic capital to speak to their Western audiences. And when they do, it is predominantly about a foreign, "hidden”, Communist China plagued with a bad historical record of anti-humanitarian events, despite the actual richness of their narratives.

\section{Discursive China in Literary Translation}

The images of China emerging from the products of translated Chinese literature evoke an exotic but dystopic cultural realm deeply mired in totalitarian rule. These images are articulated through various forms of paratext accompanying the translations and incorporated into the promotional schemes of Anglo-American publishers. But they ultimately exceed considerations of marketing and profitability, and dovetail into higher-level discourses circulating through the Western media. In this regard, translations and their paratexts constitute windows through which we can observe 
parallels between a discursive China produced through textual practices such as translation and dominant Western images of the country.

In his book Western Images of China, Colin Mackerras illustrates how the image of China in the West has undergone modulations over time, observing that "biases that judge China and the Chinese harshly are more characteristic of some periods than others, but they are found at all times to some degree or another” (Mackerras 1999, 184). Prevailing Western narratives about China have indeed been derogatory at various points in history. As Julia Lovell reminds us, in the early twentieth century, the British imagination of Chinese people was replete with stock images of the Fu Manchu-style criminal: the Chinese man was pictured as the "crafty yellow face twisted by a thin lipped grin” (Lovell 2013, x) in children’s stories, and he was invariably the antagonist in stage plays. Through media representations of every kind, the Chinese were conceived of as a despicable race harbouring the evil intention of annihilating the cultured "white man”, culminating in a siege mentality best characterized by the slogan "Yellow Peril” (Frayling 2014).

The yellow peril motif was revived in the 1950s and 1960s, during which time, following the Communist takeover of China in 1949, the PRC was denounced by the US as an aggressive threat to the international community (Mackerras 1999, 83-96). This demonstrates inter-discursivity between political and popular narratives as far as the cultural imaging of China is concerned. More important to the main argument in this article, Western perceptions of China, which saw positive adjustments in the 1970s and early 1980s, took a sharp turn after 1989: "In political terms the Beijing massacre is the main event that has caused a fundamental change of Western images, from dominantly positive existing before 1989, to the mainly negative which have prevailed since”, says Mackerras (ibid., 154-155). The tension in Tibet further fuels this negative 
imaging, such that "[a] persistent issue in Western images of China has been that China was a despotism or was/is totalitarian” (186).

In translated literature, the tendency to construct a tyrannical China, through the selection of sensitive titles and the use of rhetorical devices in paratexts, falls in line with these broad trends of Western perceptions of China. A coherence of discourses thus obtains at the macro-ideological and micro-textual levels. A similar phenomenon has been attested in English translations of contemporary Chinese poetry. Huang $(2002,166)$ astutely observes that in Western academia, the translation of Chinese poetry into English often becomes “a typical ethnographic strategy” that “textualiz[es] a Chinese reality”:

Indeed, when treated thematically, much of what has been available in English translation of contemporary Chinese poetry often yields the expected content, familiar in political science and in self-serving U.S. narratives of what it is like to suffer under nondemocratic regimes. Typically, the poems that are introduced tell the story of fighting for democracy, yearning for freedom, awakening to self-consciousness, and rediscovering subjectivity. In other words, these are poems that may easily be contextualized with respect to an image of contemporary China familiar to U.S. readers. (Huang 2002, 166)

To Huang, this kind of motivated reading, as framed by “an assumed political reality” (2002, 165), leads to "ideological reduction and ethnographic essentialization”. It "reduces Chinese poetry to expressions of a few political themes rendered in precise imagery and makes the translation itself into an ethnographic account of the political reality of contemporary China” (ibid., 173). I argue that this “problematic model of literary studies” (ibid.,176), with a 
“problematically self-serving contextualization” (ibid., 166), is in operation in literary translation in general, where translation plays out the ethnographic image that is perpetuated in official and popular discourses. My examples have indicated that this image is rather homogenous, namely that of a "totalitarian regime oppress[ing] millions of people who fight for individual freedom and self-expression” (ibid., 175). I am not suggesting that there is no such thing as totalitarianism in China, or that such movements or events as the Great Leap Forward, Cultural Revolution, and the Tiananmen Incident did not happen in history. Instead, I am arguing that these factual events are often metonymically taken to represent the essence of China, and serve as ideological filters through which contemporary Chinese literature is selectively translated, paratextually treated, and partially received.

Within the geopolitical context of China’s global ascendance as a world power and its perceived hegemony in the Asia-Pacific region and beyond, the significance of the phenomenon discussed here goes well beyond literature and translation. Literary translation is but part of a wider programme of Anglophone textual practices where China stands as a subject; these various practices tend to triangulate around a self-fulfilling idea of what China is or will become, as if the latter were an object that can be exhaustively signified with a set of conceptual terminology. For example, there has in recent years been a proliferation of quasi-academic English titles treating the theme of China's meteoric rise, many of which construe China as an imminent threat to the international order. A very tentative list would give us such telling titles as Will China Dominate the $21^{\text {st }}$ Century? by Jonathan Fenby, When China Rules the World by Martin Jacques, Is China Buying the World? by Peter Nolan, and Devouring Dragon: How China's Rise Threatens our Natural World by Craig Simons. It is not too much of a stretch to suggest that these writings form a textual continuum with the literary translations we have looked at, reinforcing each other's 
narratives about a politically repressive China rising exponentially to dictate the world order. They display a “sheer knitted-together strength” (Said 1978/2003, 6) befitting a coherently powerful discourse.

These narratives are extremely productive, and that is because the knowledge structures governing the textual practices, both translation and writing, are also those that underlie dominant discourses on China. Together, these discourses and practices circumscribe the ways in which China is figured in concrete representations. To be sure, there is nothing to prevent individuals from thinking or talking about China in line with their various subjectivities. That said, there are certain discursive formations that render China an overdetermined sign, such that individual interpretations are inevitably oriented toward “doxological ideas”, to use Said’s (1978/2003, 22) term. There are indeed strong parallels between the knowledge structures facilitating the production of discursive China today and those that facilitated the Orientalist imagining of the Islamic Near East in the colonial era. Not unlike Orientalist writings of the past, modern Anglophonic textual refractions of China operate as a form of “discursive constituency”, a “cultural praxis”, which “operates as representations usually do, for a purpose, according to a tendency, in a specific historical, intellectual, and even economic setting” (273). While China as a political entity is real, discursive China is an invention of "a political vision of reality whose structure promoted the difference between the familiar (Europe, the West, 'us') and the strange (the Orient, the East, 'them')” (43). It is almost curious to note - and this is perhaps not totally serendipitous - that the range of ideas that were applied by European imperialists to the exotic Near East, including “Oriental despotism, Oriental splendor, cruelty, sensuality” (4) see their reincarnation in the Far East today, where China has become an "unchanging abstraction” (8) generated by a very specific mode of discourse and system of representation. The publishing 
industry is an institution supporting this mode and system, and literary translation, together with its paratextual apparatuses, is its vital instrument.

This, of course, is only half the story told. China, on her part, is not a passive player in this game called cultural politics; on the contrary, it has in recent years stepped up its efforts to programmatically represent and project itself to the West. One of the portals through which this takes shape is the systematic translation of Chinese texts on traditional culture into English.

Potential tension ensues: as China seeks to commodify itself in a way that favours its accretion of soft power, the West mitigates this soft power through its own cross-cultural imaginings of China. Discursive constructions and counter-constructions, within which translation performs a major role, are ultimately a part of larger power struggles on the global stage.

Notes

${ }^{1}$ A second English edition was published in 2008 by the US publisher Black Cat, an imprint of Grove Press.

${ }^{2}$ Italics in original.

${ }^{3}$ All instances of the word China refer specifically to the People's Republic of China (PRC).

${ }^{4}$ We learn from the introduction to Serve the People! (Yan 2007, n.p.) that as early as 1994, Yan’s Xia riluo

(Summer Day's End) was banned, after which he was forced to write self-criticisms for four months (a form of light punishment meted out by the Chinese authorities that requires alleged wrong-doers to reflect upon and repent their political incorrectness).

${ }^{5}$ I am adapting Pierre Bourdieu's notion of habitus, which consists of “durable and transposable set[s] of principles of perception, appreciation, and action, capable of generating practices and representation that are (usually) adapted to the situation” (Bourdieu 1991, 29).

${ }^{6}$ Dream of Ding Village was shortlisted for the Man Asian Literary Prize and the Independent Foreign Fiction Prize in 2012. These awards are indicative of the cultural capital the novel has accrued in the Anglophone literary world. 
${ }^{7}$ In Chinese, the usual term used by the media is Tiananmen shijian or Liu Si [June Fourth] shijian, where shijian is a relatively neutral term that best translates as "event" or "incident".

${ }^{8}$ Cf. the blurb introducing Yang Jisheng’s Tombstone (Farrar, Strauss and Giroux edition): “Tombstone is a testament to inhumanity and occasional heroism that pits collective memory against the historical amnesia imposed by those in power" (Yang 2012).

${ }^{9}$ As an example, for the term "Rightist status", the translator explains that under Mao Zedong's rule, about 700,000 people were labelled “rightists” for their disagreement with the Great Leap Forward, and that Deng Xiaoping (Mao’s successor) was responsible for the actual persecution of the dissidents (Duke 2012b, 311).

${ }^{10}$ In literature, the best example of censorship leading to a sensation has to be Gustave Flaubert, who rose in popularity after the 1857 trial of Madame Bovary. As Flaubert confessed in a letter, "My persecution has won me endless sympathy. If my book is bad, the trial will serve to make it seem better; if on the contrary it is to last, this [the trial] will be its pedestal” (cited in Ladenson 2007, 18). For a detailed survey of the censorship trials of other controversial works that have since become part of the modernist canon, see Ladenson (2007).

${ }^{11}$ A preface written by Dalai Lama, the highly-revered spiritual leader-in-exile seen by the Chinese government as a political adversary for allegedly promoting Tibetan independence, further underscores the political tone of the book. 12 The word "Shanghai" has entered the English lexicon to mean "to cheat or trick", an example of the lexicalization of Orientalist cultural attitudes.

${ }^{13}$ The choice of these two Russian authors is strategic: both Maxim Gorky (1868-1936) and Aleksandr Solzhenitsyn (1918-2008) were political activists who campaigned against totalitarianism (the Tsarist regime for Gorky, the Soviet regime for Solzhenitsyn). 


\section{Note on Contributor}

Tong King Lee is an assistant professor in translation in the School of Chinese, University of Hong Kong. He is the author of Experimental Chinese Literature: Translation, Technology, Poetics (Brill, 2015) and Translating the Multilingual City: Crosslingual Practices and Language Ideology (Peter Lang, 2013).

\section{References}

Appiah, Kwame Anthony. 1993/2012. “Thick Translation.” In The Translation Studies Reader ( $3^{\text {rd }}$ ed.), edited by Lawrence Venuti, 331-343. London: Routledge.

Baker, Mona. 2006. Translation and Conflict. London: Routledge.

Bassnett, Susan. 2014. Translation. London: Routledge.

Bourdieu, Pierre. 1991. “Questions of Method.” In Empirical Studies of Literature: Proceedings of the Second IGEL-Conference, Amsterdam 1989, edited by Elrud Ibsch, Dick Schram and Gerard Steen, 19-36. Amsterdam: Rodopi.

Casanova, Pascale. 2004. The World Republic of Letters. Translated by M.B. DeBevoise. Cambridge, MA: Harvard University Press.

Chan, Koonchung. 2012. The Fat Years. Translated by Michael S. Duke. London: Black Swan.

Damrosch, David. 2003. What is World Literature? Princeton, NJ: Princeton University Press.

Duke, Michael S. 2012a. Translator's note. In Chan Koonchung, The Fat Years, 300-307. Translated by Michael S. Duke. London: Black Swan.

Duke, Michael S. 2012b. Translator's endnotes. In Chan Koonchung, The Fat Years, 308-318. Translated by Michael S. Duke. London: Black Swan. 
Edwards, Louise. 1995/2013. “Late Twentieth Century Orientalism and Discourses of Selection.” In Vol. 1 of Towards a History of Translating, edited by Wong Wang-Chi, 267-279. Hong Kong: Chinese University Press.

English PEN. Accessed March 25. www.englishpen.org

Even-Zohar, Itamar. 1990/2012. “The Position of Translated Literature within the Literary Polysystem.” In The Translation Studies Reader ( $3^{\text {rd }}$ ed.), edited by Lawrence Venuti, 162-167. London: Routledge.

Frayling, Christopher. 2014. The Yellow Peril: Dr Fu Manchu and the Rise of Chinaphobia. London: Thames and Hudson.

Genette, Gerard. 1997. Paratexts: Thresholds of Interpretation. Translated by Jane E. Lewin. Cambridge: Cambridge University Press.

Henitiuk, Valerie. 2014. “A Crisis of Translation: Early European Encounters with Japan.” In A Companion to Translation Studies, edited by Sandra Bermann and Catherine Porter, 401-412. Chichester: Wiley Blackwell.

Huang, Yunte. 2002. Transpacific Displacement: Ethnography, Translation, and Intertextual Travel in Twentieth-century American Literature. Berkeley: University of California Press. Ladenson, Elisabeth. 2007. Dirt for Art's Sake: Books on Trial from Madame Bovary to Lolita. Ithaca, NY: Cornell University Press.

Lefevere, André. 1992. Translation, Rewriting and the Manipulation of Literary Fame. London: Routledge.

Liss, Alexander. 2003. "Images of China in the American Print Media: A Survey from 2000 to 2002.” Journal of Contemporary China 12(35): 299-318.

Liu, Xiaobo. 2012a. June Fourth Elegies. Translated by Jeffrey Yang. London: Jonathan Cape. 
Liu, Xiaobo. 2012b. No Enemies, No Hatred: Selected Essays and Poems. Cambridge, MA: Belknap Press of Harvard University Press.

Lovell, Julia. 2006. The Politics of Cultural Capital: China's Quest for a Nobel Prize in Literature. Honolulu, Hawaii: University of Hawaii Press.

Lovell, Julia. 2012. Preface to Chan Koonchung, The Fat Years, 9-21. Translated by Michael S.

Duke. London: Black Swan.

Lovell, Julia. 2013. Introduction to Lao She, Mr Ma and Son, ix-xvi. Translated by William Dolby. Melbourne: Penguin.

Ma, Jian. 2009. Beijing Coma. Translated by Flora Drew. London: Vintage.

Mackerras, Colin. 1999. Western Images of China. Rev ed. Oxford: Oxford University Press.

Mo, Yan. 2000. The Republic of Wine. Translated by Howard Goldblatt. New York: Arcade.

Mo, Yan. 2003. Red Sorghum. Translated by Howard Goldblatt. London: Arrow Books.

Mo, Yan. 2006. Life and Death are Wearing Me Out. Translated by Howard Goldblatt. New York: Arcade.

Niranjana, Tejaswini. 1992. Siting Translation: History, Post-structuralism, and the Colonial Context. Berkeley: University of California Press.

Rojas, Carlos. 2013. Translator’s note. In Yan Lianke, Lenin’s Kisses, v-ix. Translated by Carlos Rojas. London: Vintage.

Said, Edward. 1978/2003. Orientalism. New York: Penguin.

Spivak, Gayatri Chakravorty. 1993/2012. “The Politics of Translation.” In The Translation Studies Reader (3 ${ }^{\text {rd }}$ ed.), edited by Lawrence Venuti, 312-330. London: Routledge.

Su, Tong. 2010. Tattoo: Three Novellas. Translated by Josh Stenberg. Portland, ME: Merwin Asia. 
Turner, Oliver. 2014. American Images of China: Identity, Power, Policy. Abingdon: Routledge. Tymoczko, Maria. 1999. Translation in a Postcolonial Context: Early Irish Literature in English Translation. Manchester: St. Jerome.

Venuti, Lawrence. 2008. The Translator's Invisibility: A History of Translation. $2^{\text {nd }}$ ed. London: Routledge.

Wilson, Rita. 2013. “Terra Australis Incognita Even Now? The Reception of Contemporary Australian Literature in Italian Translation.” In Perspectives on Literature and Translation: Creation, Circulation, Reception, edited by Nelson and Maher, 178-194. London: Routledge.

Yan, Lianke. 2004. “Wo de ziyou zhi meng zai shouhuo li” [My dream of freedom lies in Shouhuo] (Interview). Accessed Nov 13. http://www.people.com.cn/GB/14738/14759/21866/2345446.html

Yan, Lianke. 2007. Serve the People! Translated by Julia Lovell. London: Constable.

Yan, Lianke. 2011. Dream of Ding Village. Translated by Cindy Carter. London: Consair.

Yan, Lianke. 2013. Lenin’s Kisses. Translated by Carlos Rojas. London: Vintage.

Yang, Jisheng. 2012. Tombstone: The Untold Story of Mao's Great Famine. Rpt. Translated by Stacy Mosher and Guo Jian. New York: Farrar, Straus and Giroux.

Yang, Jisheng. 2013. Tombstone: The Untold Story of Mao's Great Famine. Translated by Stacy Mosher and Guo Jian. London: Penguin.

Yu, Hua. 2012. China in Ten Words. Translated by Allan H. Barr. New York: Anchor Books. Yu, Hua. 2014. Boy in the Twilight: Stories of the Hidden China. Translated by Allan H. Barr. New York: Pantheon Books. 